\title{
The Academic Performance of Scholarship Students during Medical School
}

\section{Desempenho Acadêmico de Estudantes Bolsistas durante o Curso de Medicina}

\author{
Glaucia de-Oliveira Moreira ${ }^{1}$ \\ Silvia Passeril \\ Paulo Eduardo Neves Ferreira Velho II \\ Flavio Ferraresi ${ }^{I I I}$ \\ Simone Appenzeller ${ }^{I I}$ \\ Eliana Amaral ${ }^{I I}$
}

\section{KEY-WORDS}

- Educational Measurement.

- Medical Education.

- Social Support.

- Scholarships.

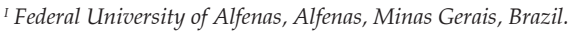

"Iniversity of Campinas, Campinas, São Paulo, Brazil.

${ }^{\text {III }}$ Federal Institute of São Paulo, Campinas, São Paulo, Brazil. 


\section{PALAVRAS-CHAVE}

- Avaliação Educacional.

- Classe Social

- Educação Médica.

- Educação Superior.

- Inclusão Educacional.

- Populações Vulneráveis.

- Responsabilidade Social

Recebido em: 4/12/18

Aceito em: 8/1/19

\section{RESUMO}

A inclusão, a adesão e o sucesso de estudantes de baixa renda na graduação são metas importantes no ensino superior brasileiro, assim como em outras partes do mundo, principalmente em cursos concorridos e em tempo integral, como o de Medicina. Este manuscrito analisa o desempenho de estudantes de graduação em Medicina, comparando dois grupos: os que se candidataram e receberam uma bolsa de estudos durante os anos acadêmicos (bolsistas) e os demais (sem bolsa). Analisamos dados de 417 estudantes de Medicina que se formaram entre 2010 e 2013, correspondendo a quatro anos de uma coorte retrospectiva, numa universidade pública gratuita no Brasil. A análise estatística foi realizada pelo teste exato de Fisher, o teste t de Student, o de Mann-Whitney e a regressão linear para comparar os escores desses grupos no sexto e décimo segundo semestres (meio e último semestres) e no exame de admissão para programas de residência médica, compostos por: escore total, teste de múltipla escolha para avaliação do conhecimento, avaliação clínica estruturada simulada, entrevista e perguntas escritas. A variável independente foi receber uma bolsa de estudos, enquanto as variáveis de controle foram idade, estratos socioeconômicos, gratificações extras para o ensino médio em instituição pública e autodeclaração de raça, pontuação no vestibular (geral e em cada área avaliada) e escolaridade dos pais. Um total de 243 alunos (58,2\%) receberam uma bolsa de estudos, a maioria como bolsa de iniciação científica (217 ou 89,3\%), enquanto 10,7\% a receberam por assistência social. A renda média per capita foi cerca de $16 \%$ menor entre os bolsistas $(p=0,01)$ em comparação com aqueles que não receberam bolsa. Os estudantes bolsistas obtiveram melhor desempenho acadêmico no sexto $(p<0,01)$ e no décimo segundo $(p<0,01)$ semestres, mas não na admissão em programas de residência médica. O bom desempenho foi independentede idade,raça, recebimento de bônus à admissão na escola médica e formação educacional dos pais. Portanto, concluímos que receber uma bolsa na graduação foi associadoa melhor desempenho dos alunos durante o curso de graduação em Medicina. Enfatizamos a importância de reforçar programas semelhantes, especialmente para ajudar a apoiar os alunos mais vulneráveis socioeconomicamente.

\section{INTRODUCTION}

In Brazil, students that begin higher education at universities come directly from high school through a very competitive process, based mainly on assessment ofknowledge. This process has generated disadvantages for students from secondary public schools coming mainly from lower socioeconomic strata. In order to improve this selection process, federal government and institutions have launched several inclusion policies, including bonuses and quotas for public high school attendance, students of black/indigenous race and low socioeconomic background ${ }^{1,2}$, as well as providing loans to pay forattending private universities. With the inclusion policies growing, questions about student performance and dropout rates due to lack of financial support have been raised ${ }^{3,4}$. In public universities, different scholarship strategies are available, not always for the purpose of socioeconomic assistance, since initially the scholarships were earmarked for the best students with the intention of starting in the world of research, guided by their professors; it was later found that some of the difficulties mentioned above could be surpassed, not only for the participants of research projects, but also for those who worked within the university for approximately 10 hours a week.

Previous studies have shown conflicting results regarding the performance of students who receive scholarships. However the number of students, years of follow up and type of undergraduate courses could have influenced these differences $^{3,5,6,8}$. Some studies have shown that students receiving a scholarship showed a more supportive attitude to colleagues outside the classroom, participated more in community service activities, engaged in more extracurricular activities ${ }^{6}$, and tended to persist in the academic career, seeking master's and doctorate degrees ${ }^{9}$.

In this study, we aim to evaluate the performance of students with the scholarship during the six-year course of medical school and during the posterior selection process for 
Medical Residency at a large and highly competitive public university in Brazil.

\section{METHODS}

Analysis was conducted of socioeconomic and performance data of students that graduated between 2010 and 2013 at the University of Campinas (Unicamp) Medical School.The Ethics Committee of the Faculty of Medical Science approved the study (IRB 515.297). Data on the socio-demographic profile, obtained from each student when applying for an undergraduate position, included current age, sex, self-declared race or color, household income, educational level of father and mother and number of family members depending on that income. Per capita income was calculated in monthly minimum wages divided by the number of people depending on the household income, calculating for minimum wages of 115.3 dollars in 2005, 159 dollars in 2006, 190 dollars in 2007 and 197 dollars in 2008.The parents' level of education was classified as fundamental school for the first 9 years, followed by 3 years corresponding to high school, both grouped as basic education, in accordance with the National Curricular Guidelines for Basic Education, and the 2014 National Education Plan. Basic schooling was considered either complete or incomplete. Higher education associated with undergraduate degree education was also reported as complete or incomplete.

Two categories of scholarships are available: those associated with research initiation projects, and those exclusively for social support. Social support scholarships for housing, food and transportation, are dependent of a detailed social selection process. Various programs support different amount of scholarships for research, including the Institutional Program for Scientific and Technological Initiation Grants (Pibic/Pibiti), financed by National Council for Scientific and Technological Development (CNPq) and Unicamp, and from the Foundation for Research Supportof the State of São Paulo (Fapesp).

The information about the cumulative undergraduate performance at six (middle) and twelve (final) semesters of medical school (GPA6 and GPA12respectively), and scholarship received, was obtained from the database of the Academic Directorate. The residency admission results were obtained from the Permanent Commission for Entrance Exams (Comvest).The five components of the assessment system for residency admission analysed included multiple-choice questions, short essay questions, clinical skills assessment (CSA), interview, and total residency admission score.

\section{Statistical analysis}

A database was set up in SPSS 18.0 and the tests to ward off the effects of possible collinearity between the variables were performed along with the cleaning of the database. For all analyses, a $p$-value less than 0.05 was considered statistically significant.

Categorical data were compared by Fisher's exact test. The Student's t-test and the Mann-Whitney test were used to analyze the receipt of scholarships with per capita income. Linear regression was used to analyze the academic performance coefficient, here named Grade Point Average (GPA) in the sixth and twelfth semesters, and the performance at the medical residence selection exam as dependent variables; required age, socioeconomic level, received bonuses for having studied at a public institution for the entirety of high school education, and the educational level or schooling of the parents were control variables.

\section{RESULTS}

\section{Demographic data}

The study included 417 medical students enrolled from 2005 to 2008. The mean age was 20 years (range 17 to 33), with a predominance of female 230 (55.1\%) students. Three hundred and thirty-nine $(81.2 \%)$ students declared themselves white, $33(7.9 \%)$ yellow, 31(7.4\%) brown, $2(0.5 \%)$ black and $2(0.5 \%)$ indigenous. Regarding household income, 35 (8.4\%) students reported receiving up to 5 minimum wages; 125 (29.9\%) students reported higher than 10; $90(21.5 \%)$ students reported a household income between 5 and 10 minimum wages. A total of $78(19.3 \%)$ households had one minimum wage per capita, with the mean greater than three in both groups. Almost half the students had parents who had completed higher education (208 or $49.8 \%$ for fathers and 194 or $46.4 \%$ for mothers), while $79(18.9 \%)$ fathers and 59 (14.1\%) mothers had completed a graduate degree.

\section{Scholarship and its impact}

Among 243 (58.2\%) students with a scholarship, 217 (89.3\%) were awarded exclusively for research activities and 20 (8.2\%) exclusively for social support, while $6(2.5 \%)$ received the scholarship for both purposes. A significant increase in the number of students benefited by scholarships was observed (Table 1).

No difference was observed between the father's ( $p=0.33$ ) or the mother's $(p=0.40)$ schooling, sexes $(p=0.21)$, age $(p=0.71)$, race $(p=0.69)$, type (private or public) of primary $(p=0.32)$ or high school $(p=0.29)$ and household income $(p=0.19)$ comparing students with and without scholarships, although there was a lower per capita income among those receiving a scholarship ( $p<0.01)$ (Table 2). 


\begin{tabular}{|c|c|c|c|c|}
\hline $\begin{array}{r}\text { Students } \\
\text { gran }\end{array}$ & $\begin{array}{l}\text { with schol } \\
\text { during C }\end{array}$ & $\begin{array}{l}\text { TABLE } 1 \\
\text { ship and/c } \\
\text { lege per ye }\end{array}$ & $\begin{array}{l}\text { scientific } \\
\text { r of admis }\end{array}$ & $\begin{array}{l}\text { itiation } \\
\text { on }\end{array}$ \\
\hline & & Year of a & mission & \\
\hline Scholarship & $\begin{array}{c}2005 \\
\text { N (\%) }\end{array}$ & $\begin{array}{c}2006 \\
\text { N (\%) }\end{array}$ & $\begin{array}{c}2007 \\
\text { N (\%) }\end{array}$ & $\begin{array}{c}2008 \\
\text { N (\%) }\end{array}$ \\
\hline Receiving & $48(47.1 \%)$ & $58(53.7 \%)$ & $63(59.4 \%)$ & $73(72.3 \%)$ \\
\hline Notreceiving & $54(52.9 \%)$ & $50(46.3 \%)$ & $43(40.6 \%)$ & $28(27.7 \%)$ \\
\hline Total & 102 & 108 & 106 & 101 \\
\hline
\end{tabular}

\begin{tabular}{|c|c|c|c|c|}
\hline Per capita $\mathrm{i}$ & TABLE & sch & rship rec & \\
\hline & Scholarship & $\mathbf{N}$ & Average & SD \\
\hline Per capita income & Yes & 224 & 3.68 & 2.39 \\
\hline & No & 162 & 4.39 & 2.64 \\
\hline
\end{tabular}

Student's t Test $(T=2,6 / p<0.01)$.

Students who received scholarships performed better in the middle $(p<0.01)$ and at the end of the medical course $(p<0.01)$ (Table 3). In the selection for medical residency, no difference was detected for any phase of the exam, including multiple choice, short essay questions, clinical skills assessment, interview and total score (Table 4).

\begin{tabular}{|c|c|c|c|c|c|c|}
\hline $\begin{array}{l}\text { Academ } \\
\text { scholars }\end{array}$ & $\begin{array}{l}\text { ic performa } \\
\text { hip in the } 6\end{array}$ & $\begin{array}{l}\text { nce a } \\
\text { h and }\end{array}$ & $\begin{array}{l}\text { BLE } 3 \\
\text { ng stud } \\
\text { th semes }\end{array}$ & $\begin{array}{l}\text { s wi } \\
s-S\end{array}$ & $\begin{array}{l}\text { and } \\
\text { ident }\end{array}$ & $\begin{array}{l}\text { ithout } \\
\text { T test }\end{array}$ \\
\hline & Scholarship & $\mathbf{N}$ & $\begin{array}{c}\text { Average } \\
\text { score }\end{array}$ & SD & $t$ & $\mathrm{p}$ \\
\hline GPA* 6 & No & 175 & 0.78 & 0.04 & -3.31 & $<0.01$ \\
\hline & Yes & 242 & 0.80 & 0.04 & & \\
\hline $\mathrm{GPA}^{*} 12$ & No & 175 & 0.81 & 0.03 & -3.49 & $<0.01$ \\
\hline & Yes & 242 & 0.83 & 0.03 & & \\
\hline
\end{tabular}

\begin{tabular}{|c|c|c|c|c|c|c|}
\hline $\begin{array}{r}\mathrm{A} \\
\text { medi } \\
\text { a }\end{array}$ & $\begin{array}{l}\text { demic perf } \\
\text { l residency } \\
\text { d without sc }\end{array}$ & $\begin{array}{r}\text { TA } \\
\text { rmar } \\
\text { rogr } \\
\text { olar }\end{array}$ & $\begin{array}{l}\text { E } 4 \\
\text { e at entra } \\
\text { ms amon } \\
\text { nip (Stud }\end{array}$ & $\begin{array}{l}\text { nce e } \\
\text { g stu } \\
\text { ent's }\end{array}$ & $\begin{array}{l}\text { ram to } \\
\text { ents } \mathrm{W} \\
\text { (test) }\end{array}$ & \\
\hline & Scholarship & $\mathbf{N}$ & $\begin{array}{c}\text { Average } \\
\text { score }\end{array}$ & SD & $T$ & $P$ \\
\hline MCQ & No & 157 & 7.29 & 0.94 & -0.50 & 0.61 \\
\hline & Yes & 225 & 7.34 & 0.92 & & \\
\hline Essays & No & 157 & 6.04 & 2.10 & 0.72 & 0.47 \\
\hline & Yes & 225 & 5.88 & 2.23 & & \\
\hline CSA & No & 157 & 6.06 & 3.00 & -0.31 & 0.75 \\
\hline & Yes & 225 & 6.16 & 3.03 & & \\
\hline Interview & No & 157 & 7.30 & 3.59 & -0.85 & 0.39 \\
\hline & Yes & 225 & 7.62 & 3.69 & & \\
\hline Total MR & No & 157 & 7.38 & 0.65 & -0.59 & 0.55 \\
\hline & Yes & 225 & 7.43 & 0.68 & & \\
\hline
\end{tabular}

$M C Q=$ multiple choice questions; $C S A=$ Clinical Skills Assessments; Total MR = final score of medical residency.

\section{DISCUSSION}

We observed an absolute increase in students receiving scholarship over the years. Those being granted scholarships were from families with lower per capita income and had a better performance during medical school.

In Brazil, research scholarship has been progressively more valued as a strategy for student-centered education and engagement. From 1986 to 1995, scientific scholarships by the national research agency increased from 1,000 to 19,000, reaching almost 28,000 between 2004 and 2010, after a decrease in 1997, 1998 and 2003. Even though almost $60 \%$ of students were awarded in this sample, the incentive is not universal and does not fit the parallel increase in positionsfor higher education in recent decades, and the new student profile ${ }^{10}$.

One issue of relying on scientific research scholarship can be observed analyzing data from the official National Council on Research $(\mathrm{CNPq})$ website. The shares of scholarships are passed on to the professors who meet the terms of the calls. Thus, the quotas for scientific initiation scholarship are proportional to the number of registered researchers, and number and size of graduate programs. Since this study was conducted at a strong research university, with more than $90 \%$ of its faculty showing a doctoral degree, the number of scholarships granted increased even more than the increase in the number of students.

Our study population differs from Pereira and Pazel$10^{11}$ regarding parent's schooling. These authors found lower household income and lower parental level of education among higher education students receiving scholarships for social support, with no difference for gender, according to the answers provided by participants at the National Examination of Performance for Higher Education Students (Enade), with national coverage. In a large Brazilian study, including 787,470 students from public and private schools, a positive association between income and performance, regardless of scholarship, was observed ${ }^{3}$. According to these studies, if, on the one hand the social capital of higher income students helps them perform better, on the other hand better financial support for those in need should help them overcome differences, giving full attention to their educational program.

It is worth noting that differences in scores may have been influenced by the large sample size, which tends to overvalue small differences, leading to statistical significance ${ }^{12}$.

For these students at Unicamp, the main reasons for applying for a research scholarship were the intention of improving their curriculum and deepen their knowledge in the area, having a closer, direct support from the professor, and, to a lesser degree, due to the financial aid ${ }^{13}$. Several studies have 
observed that students receiving research grants (regardless of socioeconomic status) develop better academic performance and personal growth ${ }^{14-20}$.

In addition, published research shows that students from underrepresented minority groups that received academic and mentoring support displayed better retention and performance ${ }^{21-23}$. Three other studies also showed marked improvement of performance associated with financial aid ${ }^{24-26}$. However, whether the better performance is due to greater financial support, the presence of a supervisor close to the student, or the scientific reasoning associated with research activities themselves (including self-management, bibliographic search, critical thinking) cannot be answered ${ }^{25,26}$.

Our findings corroborate with Boatman and Long ${ }^{6}$ who also found a better performance score (GPA) in the third year of the medical course among the talented undergraduate students of color with financial need, who received a renewable scholarship for talented students, as part of a Program named Gates Millennium Scholars (GMS). Nevertheless, after correction for race, the performance was equivalent. In our study, we observed no difference between scholarship recipients in relation to race, age, type of primary or high school, and parents' education. One question that arises is whether the scholarship recipients were actually the best performers, or whether the best students and those with the highest incomes did not participate in the scholarship programs during this period, which can be modified over time by a higher valuation given to a curriculum full of publications, especially for those who seek to subsequently pursue an academic career. However, this does not change the fact that we find a pattern contrary to other publications, where higher income would be related to better performance.

Matsumoto et al. ${ }^{7}$, evaluating the performance of students participating in the Japanese government's Quotas and Scholarship program, focused on public schools, also observed that their academic performance was superior to that of their peers.

One major limitation is that it was not possible to adequately separate students who were awarded social assistance scholarships from those who received them for research activity. We know which students received a scholarship for socioeconomic assistance $(6.2 \%)$ in the four years studied, but we cannot identify how many received the scientific scholarship that would also need economic assistance. However, we showed that per capita income among scholarship students was significantly lower than the remaining group, corroborating the good performance of the less favored students who received scholarships. This minority that was associated with the scholarships earmarked for socioeconomic aid, did not change the result of the analysis when excluded from the statistical model for income analysis. In a qualitative and quantitative study, in which 27 students from the Federal University of Santa Catarina were interviewed, 18 students affirmed receiving a work scholarship (at the university), internship scholarship, fellowship monitoring or scientific initiation as a way of maintaining subsistence in higher education ${ }^{27}$. We believe that the same may have happened among our students. It must also be noted that research scholarships for students can be directed by the faculty, who tend to select a student with outstanding performance, but can consider other factors as social disadvantage.

One point that deserves clarification is that the performance of students who were candidates for receiving scientific initiation scholarships was only taken into account for the purposes of tie-breaking, not as a primary selection criterion, and was not understood as a relevant confounding factor.

Another common discussion that arises from analysis of this research is the option of analyzing in a single group all students receiving scholarships in undergraduate courses, not stratified by the types of scholarships. This choice was made because the group was mostly homogenous, since 217 (97.31\%) received a scientific initiation fellowship, of which 130 (58.3\%) were from the Institutional Scholarship Program (Pibic), 87 (39\%) from Foundation for Research Support of the State of São Paulo (Fapesp) and $4(1.8 \%)$ others, such as the tutorial education program -PET; $20(8.2 \%)$ of the scholarships were for social support alone. Given that statistically, comparative groups with less than 25 members lose reliability, we opted to analyze the students in a single group, which due to the large sample size, would make the outliers unable to significantly influence the result; however, further studies with the division between groups should be undertaken.

There is evidence to indicate that students who enter and remain in higher education through inclusion policies are as able as other professionals ${ }^{28}$. Thus, students at a social disadvantage do not become less skilled professionals. Scholarships could therefore help these students. Additional studies are important to elucidate to what extent each component of an institutional support program can influence the performance and retention of the university student in different fields of knowledge.

\section{CONCLUSION}

Better academic performance was reported among medical students who received scholarships, despite presenting a lower household income. This study reinforces that disadvantaged household income is not necessarily reflected in ac- 
ademic disadvantage, other forms of student support during undergraduate training may contribute to better performance.

\section{ACKNOWLEDGEMENTS}

To the entire Unicamp team, and especially to Prof. Ivan Toro and Prof. Hildete Pinheiro, for all their support and assistance, which were fundamental to the development of this research.

\section{REFERENCES}

1. INEP Instituto Nacional de Estudos e Pesquisas Educacionais Anísio Teixeira. Resumo Técnico - Senso Educação Superior [Internet]. Brasilia: INEP; 2016. p. 55. [Accessed on Feb 12, 2017] Avaliable at: http:/ / download.inep.gov.br/ download/superior / censo/2014/resumo_tecnico_censo_educacao_superior_2014.pdf

2. Lima KRR. A reforma do Estado e da educação no governo do Fernando Henrique Cardoso: o ENEM como mecanismo de consolidação da reforma (The reform of the State and education in the government of Fernando Henrique Cardoso: ENEM as a mechanism to consolidate the ref [Internet]. Universidade Federal de São Carlos - UFSCar; 2005. [Accessed on Jan 3,2015] Available at: https:/ / repositorio.ufscar.br/handle/ufscar/2184

3. Souza LAR. Student assistance in the field of public higher education policy. [Internet]. Programas de Inclusão e o Ensino Superior no Brasil: O impacto do programa Universidade para Todos no desempenho dos alunos no enade. Brasília: ABRAES; 2014. 40 p. [Accessed on Jan 15, 2015] Available at: www.anup.com/portal/pagina/download-arquivo/arquivo/9

4. Alves JM. Student assistance in the field of public higher education policy. APC - UEL student profile [Internet]. 2003;5(1). [Accessed on Aug 15, 2015] Available at: http:/ / www.uel.br/revistas/ssrevista/c_v5n1_Jo.htm

5. Gois JBH. Quando raça conta: um estudo de diferenças entre mulheres brancas e negras no acesso e permanência no ensino superior. Rev Estud Fem. 2008;16(3):743-68.

6. Boatman A, Long BT. Does Financial Aid Impact College Student Engagement?: Evidence from the Gates Millennium Scholars Program. Res High Educ. 2016;

7. Matsumoto M,Takeuchi K, Owaki T, Iguchi S, Inoue K, Kashima S, Tazuma S, Maeda T. Results of physician licence examination and scholarship contract compliance by the graduates of regional quotas in Japanese medical schools: a nationwide cross-sectional survey. BMJ Open 2017;7:e019418.

8. Abella R. An analysis of the academic performance of voucher students in the opportunity scholarship program. Educ Urban Soc. 2006;38(4):406-18.
9. Nogueira MA, Canaan MG. The "iniciated": undergraduate research fellows and their academic careers. Rev TOMO. 2009;(15):41-70.

10. Bianchetti L, de Oliveira A, Ledur da Silva E, Turnes L. A iniciação à pesquisa no Brasil: políticas de formação de jovens pesquisadores. 2012;37(3):569-84.

11. Pereira RH., Pazello, E T. Diferença de desempenho entre alunos bolsistas e não bolsistas matriculados no ensino superior : uma análise a partir dos microdados do Enade Raphael H . N . Pereira, Elaine T . Pazello (supervisor) [Internet]. Faculdade de Economia, Administração e Contabilidade de Ribeirão Preto, USP, SP; 2013. p. 1. [Accessed on July 12, 2016] Available at: https://uspdigital.usp.br/ siicusp/cdOnlineTrabalhoVisualizarResumo?numeroInsc ricaoTrabalho $=2592$ \&numeroEdicao $=20$

12. Cooter R, Erdmann JB, Gonnella JS, Callahan CA, Hojat $\mathrm{M}, \mathrm{Xu}$ G. Economic Diversity in Medical Education. Eval Health Prof [Internet]. 2004;27(3):252-64. [Accessed on Aug 20,2013] Available at: http://journals.sagepub.com/ doi/10.1177/0163278704267041

13. Bridi JCA. The scientific initiation in university education. Campinas/SP: Unicamp; 2004.

14. Caberlon VI. Research and graduation in the FURG: in search of understanding sod different horizons. Porto Alegre/RS: Faculty of Education/UFRGS; 2003.

15. Breglia VLA. Graduation training: contributions, impacts and repercussions of PIBIC. Rio de Janeiro: Pontifical Catholic University of Rio de Janeiro; 2002. p. 210.

16. Pires RCM. The contribution of undergraduate scientific research in training undergraduate students in state universities. Salvador: School of Education, Federal University of Bahia; 2002. p. 120.

17. Massi L, Queiroz SL. Estudos sobre iniciação científica no Brasil: Uma revisão. Cad Pesqui [Internet]. 2010;40(139):173-97. [Accessed in 2013 oct 20] Avaliable at: http: / / www.scopus.com/inward/record.url?eid=2-s2.0$-77955588359 \&$ partnerID=tZOtx3y1

18. Vargas MLF. Ensino superior, assistência estudantil e mercado de trabalho: um estudo com egressos da UFMG. Avaliação. 2011;16(1):149-63.

19. Areephanthu CJ, Bole R, Stratton T, Kelly TH, Starnes CP, Sawaya BP. Impact of Professional Student Mentored Research Fellowship on Medical Education and Academic Medicine Career Path. Clin Transl Sci. 2015;8(5):479-83.

20. Haave, N.; Audet D. Evidence in support of removing boundaries to undergraduate research experience. Collect essay Learn Teach. 2013;6:105-10. 
21. Murray TA. Factors that promote and impede the academic success of African American students in prelicensure nursing education: an integrative review. J Nurs Educ. 2015;54(9):S74-81.

22. Cowan, Patricia A ; Weeks, Y'Esha ; Wicks MN. Promoting success of ethnic minority and male students in an accelerated, entry-level master of nursing program: the SUSTAIN Program. J Nurs Educ. 2015;54(9):S112-5.

23. Ooms A, Fergy S, Marks-Maran D, Burke L, Sheehy K. Providing learning support to nursing students: A study of two universities. Nurse Educ Pract [Internet]. Elsevier Ltd; 2013;13(2):89-95. [Accessed in 2015 feb 02] Available at: http:/ /dx.doi.org/10.1016/j.nepr.2012.07.011

24. Indiana Commission for Higher Education. Reforming Student Financial Aid to Increase College Completion [Internet]. Indianapolis: Indiana Commission for Higher Education; 2015. p. 38. [Accessed in 2017 jull 05] Available at: https://www.in.gov/che/files/2015_Indiana_Financial_Aid_Reform_13015_Pages.pdf

25. Mayer AK. Performance-based scholarships: replication at six sites using randomized controlled trials. Copyright; 2014. p. 21. [Accessed on Feb 17, 2017 ] Available at: http:/ / files.eric.ed.gov/fulltext/ED558500.pdf

26. Mayer, A.K.; Patel, R.; Gutierrez M. Four-year effects on degree receipt and employment outcomes from a performance-based scholarship in Ohio. MDRC - Building Knowledge to Improve Social Policy; 2015. p. 23.

27. Zago N. Do acesso à permanência no ensino superior: percursos de estudantes universitários de camadas populares. Rev Bras Educ. 2006;

28. Wainer, J,; Melguizo T. Políticas de inclusão no ensino superior: avaliação do desempenho dos alunos baseado no Enade de 2012 a 2014. Educação e Pesquisa; 2017.

\section{CONTRIBUTIONS}

This work contributes to new important elements to assist in the planning and implementation of institutional or public policies for socio-economic inclusion in higher education.

\section{CONFLICT OF INTERESTS}

There are no conflicts of interest to be declared by the authors of this article.

POSTAL ADDRESS

Profa. Gláucia de Oliveira Moreira UNIFAL-MG: UNIDADE EDUCACIONAL SANTA CLARA - ALFENAS

Av. Jovino Fernandes Sales, 2600 - Prédio I, Sala 519-A

Bairro Santa Clara - Alfenas/MG

CEP: $37133-840$

E-mail: glaucia.moreira@unifal-mg.edu.br 